\title{
Anchovy Drying Using Infrared Radiation
}

\author{
${ }^{1}$ Watcharin Dongbang and ${ }^{2}$ Anirut Matthujak \\ ${ }^{1}$ Department of Mechanical Engineering, \\ Faculty of Engineering, Burapha University, Thailand \\ ${ }^{2}$ Department of Mechanical Engineering, \\ Faculty of Engineering, Ubon Ratchathani University, Thailand
}

Received 2013-03-19, Revised 2013-03-19; Accepted 2013-04-26

\begin{abstract}
The present study investigated the drying of anchovy using infrared radiation experimentally; in addition, the dimensionless heat transfer coefficient in terms of Nusselt's number was also investigated. The anchovy was dried from $78 \pm 1 \%$ wb down to $20 \pm 1 \%$ wb. The drying conditions were infrared power range $400-800$ $\mathrm{W}$, hot air temperatures range $50-70^{\circ} \mathrm{C}$ and hot air velocity range $0.5-1.5 \mathrm{~ms}^{-1}$. The lowest drying time to reduce the moisture content was found at an air temperature of $70^{\circ} \mathrm{C}$ and velocity of $1.5 \mathrm{~ms}^{-1}$. Drying took 446, 390 and $223 \mathrm{~min}$ at 400, 600 and $800 \mathrm{~W}$ of infrared power, respectively. The increase in drying temperature, hot air velocity and infrared power were significant factors for decreasing the moisture and darkness of dried anchovy. The modified correlations of Nusselt's number for the anchovy drying could fit the experimental data quite well within $\pm 10 \%$ deviation.
\end{abstract}

Keywords: Anchovy, Drying Kinetics, Infrared Radiation, Nusselt's Number

\section{INTRODUCTION}

Anchovy (Stolephorus indicus) is a species of fish in the Engraulidae family (Czerner and Yeannes, 2013). It is the one of the small fish that can be found in most tropical areas of the Gulf of Thailand. It can be crispfried or used to make fish-based culinary products such as fish sauce or used in curries. The initial moisture content is rather high. This is one of the most important factors affecting the quality of anchovy during storage and subsequent handling. It must have the moisture reduced to add quality and prevent deterioration during storage (Ghaly and MacDonald, 2012a; Sevik, 2013).

Direct solar drying has traditionally been used, except in areas where sunshine is irregular or insufficient and when strict sanitation is required (Ghaly and MacDonald, 2012b). For thermal drying, conduction and convective heat transfer have mainly been used (Basri et al., 2012) as well as radiant heat transfer (Niamnuya et al., 2012). Infrared drying has been investigated for obtaining high quality dried food such as soybean, (Niamnuya et al., 2012), apple (Cuccurullo et al., 2012), rice (Insorn et al., 2010) and fruit leather
(Jaturonglumlert and Kiatsiriroat, 2010). The difference in drying mechanism between convectional drying and infrared radiation affects the difference in energy cost, drying time and food quality.

Heat transfer coefficient mechanisms can be investigated directly in terms of dimensionless variables. It is a common engineering practice and thus theory has been derived for dimensionless groups and numbers such as Reynolds, Nusselt and Prandtl (Geetha and Moorthy, 2011; Jaturonglumlert and Kiatsiriroat, 2010).

The objective of this study is to study the drying kinetics such as infrared power, air temperature and air velocity and in addition to modify the correlations for predicting the heat transfer coefficient in term of Nusselt's number.

\subsection{Mass Diffusivity}

The moisture movement inside the particle was developed based on Fick's second law of diffusion (Shackelford and Moore, 2013; Dongbang et al., 2010). The anchovy was assumed to be an infinite length cylinder and the equation of conservation of energy was as follows: Corresponding Author: Watcharin Dongbang, Department of Mechanical Engineering, Faculty of Engineering, Burapha University, Thailand 


$$
\frac{\partial \mathrm{M}}{\partial \mathrm{t}}(\mathrm{r}, \mathrm{t})=\mathrm{D}\left[\frac{\partial^{2} \mathrm{M}}{\partial \mathrm{r}^{2}}+\frac{\mathrm{c}}{\mathrm{r}} \frac{\partial \mathrm{M}}{\partial \mathrm{r}}\right]
$$

The variable $M$ was the moisture content at any time, $\mathrm{D}$ was the mass diffusivity of anchovy, $\mathrm{t}$ was the drying time, $r$ was the radial distance from the center of the anchovy and $\mathrm{c}$ was a constant. The Equation 1 has been solved as follows:

$$
\mathrm{MR}=\sum_{\mathrm{n}=1}^{\infty} \frac{4}{\mathrm{~b}_{\mathrm{n}}^{2}} \exp \left[-\frac{\mathrm{b}_{\mathrm{n}}^{2} \mathrm{Dt}}{\mathrm{r}_{\mathrm{c}}^{2}}\right]
$$

The variable $r_{c}$ was the radius of the anchovy, MR was the average moisture ratio at any time and $b$ was the root of Bessel's function of order zero. For a long time, variable $n$ can be equal to 1 . The mass diffusivity can be increased with the increase in drying temperature (Zlatanovi et al., 2013). The Equation 2 can be further simplified to a straight line equation as follows Equation 3:

$$
\ln (M R)=\ln \left[\frac{4}{b_{n}^{2}}\right]-\left[\frac{b_{n}^{2} \mathrm{D}}{r_{c}^{2}}\right] t
$$

For determining the mass diffusivity (D), the slope of the relationship between $\ln (\mathrm{MR})$ and time $(\mathrm{t})$ was computed and then $\mathrm{D}$ was calculated as follows Equation 4:

$$
\text { Slope }=\frac{b_{n}^{2} D}{r_{c}^{2}}
$$

The temperature effect can be modeled by using the well know Arrhenius type relationship Equation 5:

$$
\mathrm{D}=\mathrm{D}_{\mathrm{o}} \exp \left[\frac{\mathrm{E}_{\mathrm{a}}}{\mathrm{RT}}\right]
$$

The variable, $D_{0}$ was the Arrhenius' factor, $E_{a}$ was the activation energy $\left(\mathrm{kJ}^{\mathrm{kgmol}} \mathrm{kgm}^{-1}\right), \mathrm{R}$ was the universal gas constant $\left(8.314 \mathrm{~kJ} .\left(\mathrm{kgmol}^{-1} \cdot \mathrm{K}^{-1}\right)\right.$ and $\mathrm{T}$ was the absolute temperature $(\mathrm{K})$. The moisture ratio in Equation (2) was initially described by law is (Ghaly and MacDonald, 2012a) based on Newton's law of cooling in heat transfer and has often been used to explain the mass transfer in thin layer drying as follows Equation 6:

$$
M R=\frac{M_{t}-M_{e}}{M_{\text {in }}-M_{e}}
$$

where, MR was the moisture ratio, $\mathrm{M}_{\mathrm{t}}$ was the moisture content at any time, $M_{\text {in }}$ and $M_{e}$ were initial and equilibrium moisture contents, respectively.

\subsection{Heat Convection}

The classical concepts can be written in dimensionless form in terms of Nusselt's Number (Geetha and Moorthy, 2011). The total heat transfer coefficient $\left(h_{t}\right)$ is a combination of the convection $\left(h_{c}\right)$, conduction $\left(h_{d}\right)$ and radiation $\left(h_{r}\right)$ which can be written as follows Equation 7:

$\mathrm{h}_{\mathrm{t}}=\mathrm{h}_{\mathrm{c}}+\mathrm{h}_{\mathrm{d}}+\mathrm{h}_{\mathrm{r}}$

$h_{t}$ was measured by the total heat transfer $\left(q_{t}\right)$ in the drying processes, assuming the heat loss through thermal conduction and the net radiation between the anchovy and its environment were neglected. It was experimentally observed that heat conduction had no significant effect over temperature evolution during drying (Zlatanovi et al., 2013). The rate of heat absorbed by the anchovy can be made equal to the summation of the convection heat flux $\left(\mathrm{q}_{\mathrm{c}}\right)$ and the net radiation heat flux $\left(\mathrm{q}_{\mathrm{r}}\right)$ as follows Equation 8 (Jaturonglumlert and Kiatsiriroat, 2010):

$\mathrm{q}_{\mathrm{t}}=\mathrm{q}_{\mathrm{c}}+\mathrm{q}_{\mathrm{r}}$

Since Equation 9:

$\mathrm{q}_{\mathrm{t}}=\mathrm{h}_{\mathrm{c}} \mathrm{A}\left(\mathrm{T}_{\mathrm{G}}-\mathrm{T}_{\mathrm{s}}\right)+\mathrm{h}_{\mathrm{r}}\left(\mathrm{T}_{\mathrm{IR}}-\mathrm{T}_{\mathrm{s}}\right)$

The convection heat transfer coefficient $\left(h_{c}\right)$ in the surface area (A) can be calculated without dimensions in terms of the Nusselt's number. The variables $T_{G}, T_{S}$ and $T_{I R}$ were the temperatures of the gas near the surface, surface of anchovy and the infrared radiation, respectively. In addition, the radiative coefficient $\left(\mathrm{h}_{\mathrm{r}}\right)$ in the process can be calculated as follows Equation 10:

$\mathrm{h}_{\mathrm{r}}=\sigma \phi\left(\frac{\mathrm{T}_{\mathrm{IR}}^{4}-\mathrm{T}_{\mathrm{s}}^{4}}{\mathrm{~T}_{\mathrm{IR}}-\mathrm{T}_{\mathrm{s}}}\right)$

The overall absorption coefficient $(\phi)$ could be calculated from the emissivity of the product surface $(\varepsilon)$ and the radiation shape factor $\left(\mathrm{F}_{1-2}\right)$ as follows Equation 11:

$$
\phi=\varepsilon_{1} \varepsilon_{2} \mathrm{~F}_{1-2}
$$

The total heat transfer $\left(\mathrm{q}_{\mathrm{t}}\right)$ and total heat transfer coefficient $\left(h_{t}\right)$ could be written as follows Equation 12: 
$\mathrm{q}_{\mathrm{t}}=\mathrm{h}_{\mathrm{t}} \mathrm{A}\left(\mathrm{T}_{\mathrm{G}}-\mathrm{T}_{\mathrm{s}}\right)$

\section{MATERIALS AND METHODS}

\subsection{Materials}

Fresh anchovies from the Gulf of Thailand were investigated. They were maintained in ice from capture until arriving in the laboratory. For sample preparation, anchovies were washed and had size from $5 \pm 1 \mathrm{~cm}$ in length and $6 \pm 2 \mathrm{~mm}$ in diameter. The samples were put in a thin layer on a $200 \times 200 \mathrm{~mm}$ square tray with net weight of $200 \mathrm{~g}$. The initial moisture content was determined by oven drying at $105^{\circ} \mathrm{C}$ until constant weight based on the AOAC method (Czerner and Yeannes, 2013) was found to be $78 \pm 1 \%$ wb.

\subsection{Infrared Heating}

Infrared Radiation (IR) was transmitted as an electromagnetic wave which penetrates the anchovies and was then converted to heat (Niamnuya et al., 2012; Cuccurullo et al., 2012). It ranged from 0.78 to $1000 \mu \mathrm{m}$ in wavelength. The far Infrared Radiation (FIR) mainly ranged from 2.5 to $30 \mu \mathrm{m}$ with high emissivity in the long wavelength infrared region. For this study, an FIR heater was made from fine ceramics and Nichrome wire and operated at peak wavelength from 7 to $16 \mu \mathrm{m}$ and maximum temperature was estimated as $400^{\circ} \mathrm{C}$. It was operated at $220 \mathrm{~V}$ with a maximum power of $800 \mathrm{~W}$.

\subsection{Apparatus}

A schematic sketch of the apparatus is shown in Fig. 1. The blower was used to supply air into a drying chamber and the speed varied by electronic invertors. The air velocities were varied from $0.5-1.5 \mathrm{~ms}^{-1}$ which was measured by an anemometer with an accuracy of $\pm 0.1 \mathrm{~m} / \mathrm{s}$ at the position over the anchovies. An electrical heater heated the entering air which was controlled by a PID controller with an accuracy of $\pm 1{ }^{\circ} \mathrm{C}$. The drying chamber was insulated using thick plywood (lined inside with aluminum foil). An infrared heater was installed inside the drying chamber. The distance between the anchovy and the infrared heater was fixed at $10 \mathrm{~cm}$. The weight of anchovy was measured using an electronic balance with an accuracy of $\pm 0.01 \mathrm{~g}$. The air temperature and the relative humidity were controlled by digital controller, which displayed with an accuracy of $\pm 0.5^{\circ} \mathrm{C}$ and $0.25 \%$, respectively. The surface temperature $\left(\mathrm{T}_{\mathrm{s}}\right)$ of the anchovies was measured by inserting a K-type thermocouple into the center of an anchovy. The gas temperatures $\left(\mathrm{T}_{\mathrm{G}}\right)$ were measured by thermocouple wire which was kept inside an aluminum rod to protect from radiation.

\subsection{Drying Conditions}

The drying conditions were set with different combinations of three infrared powers of 400, 600 and $800 \mathrm{~W}$ and three air Temperatures $\left(\mathrm{T}_{\mathrm{a}}\right)$ of 50, 60 and $70^{\circ} \mathrm{C}$; in addition, three air Velocities (V) were set at 0.5 , 1.0 and $1.5 \mathrm{~ms}^{-1}$. The relative humidity of the air was measured throughout the experiment and ranged from 50 to $60 \%$. A sample weight of $200 \mathrm{~g}$ was dried with each drying condition. Drying tests were performed when the drying reached the steady state, which normally took 30 min. The experimenting was repeated three times and the average data was evaluated for analyzing.

\subsection{Numerical Method}

The method of least squares (Yang and $\mathrm{Xu}, 2013$ ) was used to calculate the parameters of Nusselt's Number $(\mathrm{Nu})$. For this research, terms for Reynold's number $\left(\mathrm{Re}_{\mathrm{p}}\right)$ and Prandtl's number $(\mathrm{Pr})$ were included in the apparent convective transfer due to the moisture evaporation from a wet surface in the standard formula of $\mathrm{Nu}$ (Lovineh et al., 2013) as follows:

$\mathrm{Nu}=\frac{\mathrm{h}_{\mathrm{t}} \mathrm{d}}{\mathrm{k}}=\mathrm{aRe}_{\mathrm{p}}^{\mathrm{b}} \operatorname{Pr}^{\mathrm{c}}$

Taking the logarithm of Equation 13 as follows:

$\log (\mathrm{Nu})=\log (\mathrm{a})+\mathrm{b} \log \left(\mathrm{Re}_{\mathrm{p}}\right)+\mathrm{c} \log (\operatorname{Pr})$

and assigning:

$\mathrm{z}=\log (\mathrm{Nu}), \mathrm{x}=\log \left(\operatorname{Re}_{\mathrm{p}}\right), \mathrm{y}=\log (\mathrm{Pr})$

$a_{0}=\log (a), a_{1}=b, a_{2}=c$

we substitute in Equation 14 with the above notation Equation 15:

$\mathrm{z}=\mathrm{a}_{0}+\mathrm{a}_{1} \mathrm{x}+\mathrm{a}_{2} \mathrm{y}$

$\mathrm{m}$ pairs of data points were available and take the summation as follows:

$\mathrm{E}=\sum_{\mathrm{i}=1}^{\mathrm{m}}\left[\left(f\left(\mathrm{x}_{\mathrm{i}}, \mathrm{y}_{\mathrm{i}}\right)-\mathrm{z}_{\mathrm{i}}\right)\right]^{2} \rightarrow \min$ mum 


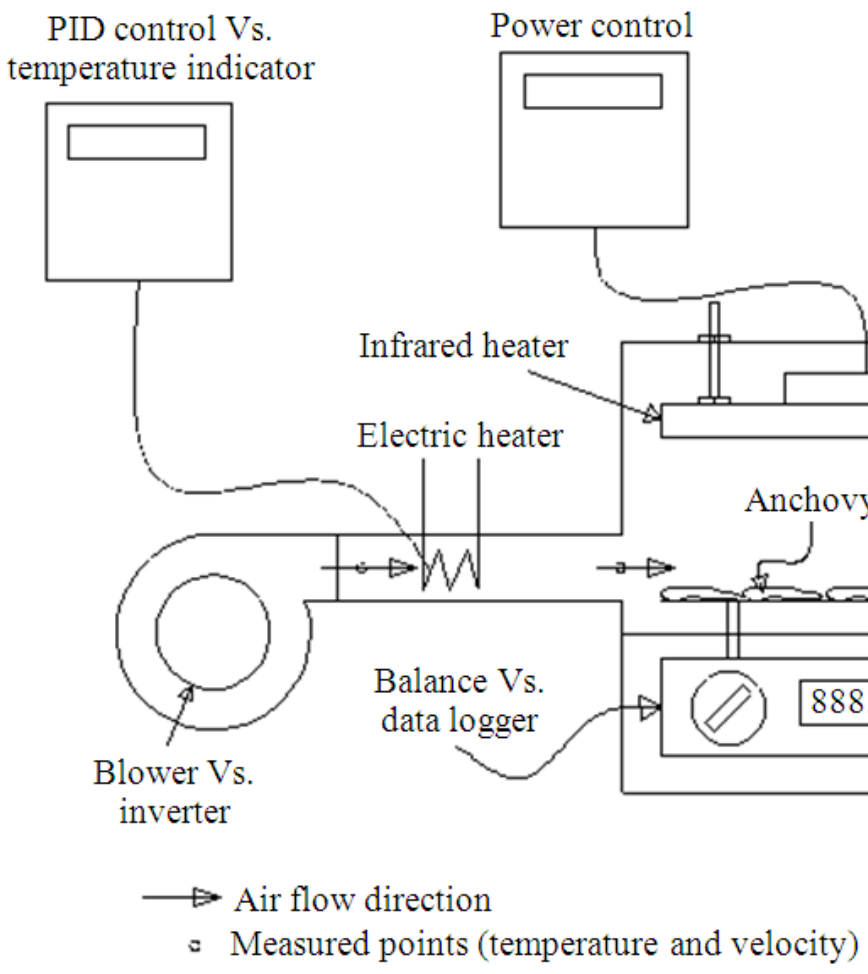

Fig. 1. Infrared drying apparatus

The minimum occurs when the partial derivatives of Equation 16 with respect to $\mathrm{a}_{0}, \mathrm{a}_{1}$ and $\mathrm{a}_{2}$ equal zero as follows:

$\frac{\partial \mathrm{E}}{\partial \mathrm{a}_{0}}=\sum 2\left[\mathrm{a}_{0}+\mathrm{a}_{1} \mathrm{x}_{\mathrm{i}}+\mathrm{a}_{2} \mathrm{y}_{\mathrm{i}}-\mathrm{z}_{\mathrm{i}}\right](1)=0$

$\frac{\partial \mathrm{E}}{\partial \mathrm{a}_{1}}=\sum 2\left[\mathrm{a}_{0}+\mathrm{a}_{1} \mathrm{x}_{\mathrm{i}}+\mathrm{a}_{2} \mathrm{y}_{\mathrm{i}}-\mathrm{z}_{\mathrm{i}}\right]\left(\mathrm{x}_{\mathrm{i}}\right)=0$

$\frac{\partial \mathrm{E}}{\partial \mathrm{a}_{2}}=\sum 2\left[\mathrm{a}_{0}+\mathrm{a}_{1} \mathrm{x}_{\mathrm{i}}+\mathrm{a}_{2} \mathrm{y}_{\mathrm{i}}-\mathrm{z}_{\mathrm{i}}\right]\left(\mathrm{y}_{\mathrm{i}}\right)=0$

Dividing Equation 17 by 2 and separating the above three equations into individual terms, the three linear simultaneous equations are expressed in matrix form as follows:

$$
\left[\begin{array}{ccc}
\mathrm{m} & \sum \mathrm{x}_{\mathrm{i}} & \sum \mathrm{y}_{\mathrm{i}} \\
\sum \mathrm{x}_{\mathrm{i}} & \sum \mathrm{x}_{\mathrm{i}}^{2} & \sum \mathrm{x}_{\mathrm{i}} \mathrm{y}_{\mathrm{i}} \\
\sum \mathrm{y}_{\mathrm{i}} & \sum \mathrm{x}_{\mathrm{i}} \mathrm{y}_{\mathrm{i}} & \sum \mathrm{y}_{\mathrm{i}}^{2}
\end{array}\right]\left[\begin{array}{c}
\mathrm{a}_{0} \\
\mathrm{a}_{1} \\
\mathrm{a}_{2}
\end{array}\right]=\left[\begin{array}{c}
\sum \mathrm{z}_{\mathrm{i}} \\
\sum \mathrm{x}_{\mathrm{i}} \mathrm{z}_{\mathrm{i}} \\
\sum \mathrm{y}_{\mathrm{i}} \mathrm{z}_{\mathrm{i}}
\end{array}\right]
$$

The solution of Equation 18 provides the values of $\mathrm{a}_{0}, \mathrm{a}_{1}$ and $\mathrm{a}_{2}$; in addition, the values of $\mathrm{a}, \mathrm{b}$ and $\mathrm{c}$ were known. The values were substituted to an Equation 13.

\section{RESULTS}

\subsection{Drying Kinetics}

The results obtained in this study were as follows. The heat and moisture transfer can be increased by increasing the infrared power, drying air temperature and air velocity. Moisture content vs drying time and drying rate vs drying time at various infrared powers of 400, 600 and 800 Watts, air velocity of $0.5 \mathrm{~ms}^{-1}$ and hot air temperature of $50^{\circ} \mathrm{C}$ are shown in Fig. 2 and 3 respectively.

As seen from the previous figures, the moisture contents reduced rapidly at the beginning and then decreased slowly with increase in drying time. The drying time to reduce the moisture content of samples of anchovy from the $78 \pm 1 \%$ wb initial value to $20 \pm 1 \%$ wb final value at an air temperature of $50^{\circ} \mathrm{C}$ and velocity of $0.5 \mathrm{~ms}^{-1}$ were 687,598 and $343 \mathrm{~min}$ at 400,600 and 800 $\mathrm{W}$ infrared power, respectively. 
Watcharin Dongbang and Anirut Matthujak / American Journal of Applied Sciences, 10 (4): 353-360, 2013

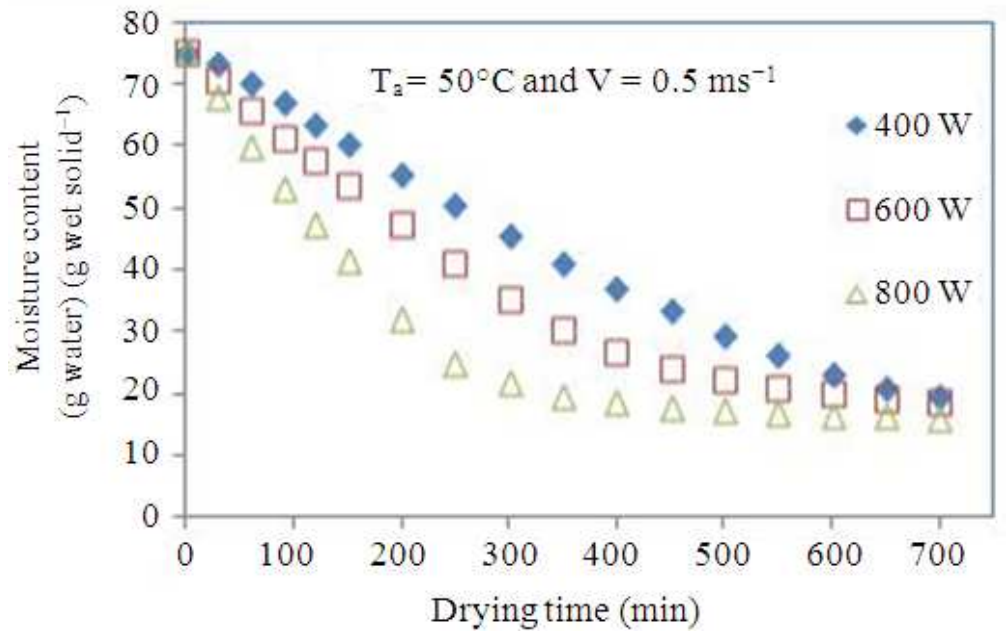

Fig. 2. Drying curve of anchovy vs infrared power

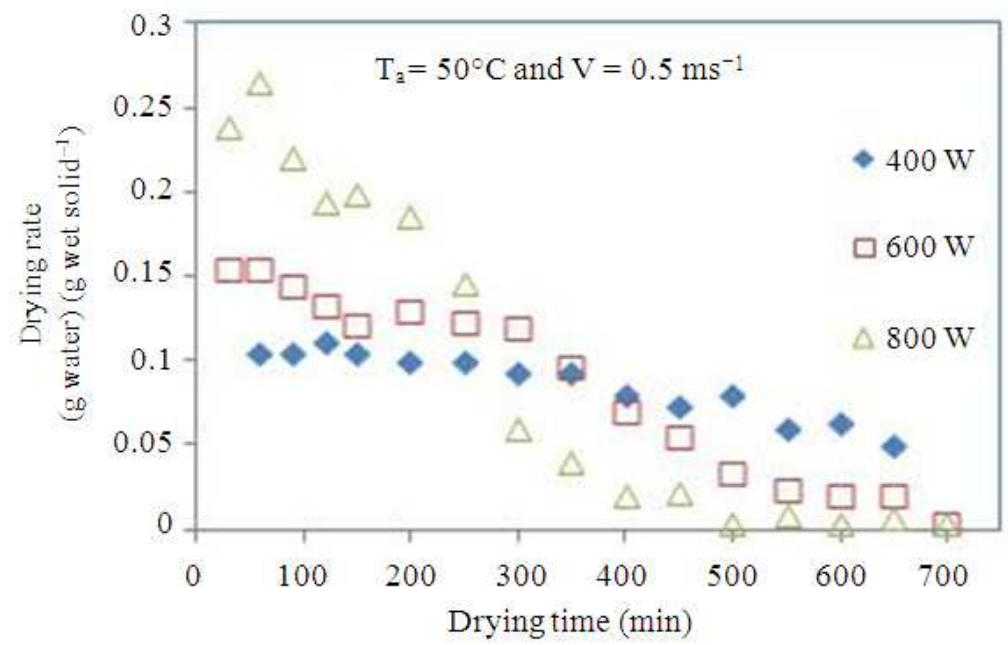

Fig. 3. Drying rate of anchovy vs infrared power

Table 1. Experimental drying time for dehydrating

\begin{tabular}{|c|c|c|c|c|}
\hline \multirow[b]{2}{*}{$\begin{array}{l}\text { Hot air temperature, } \\
\mathrm{T}_{\mathrm{a}}\left({ }^{\circ} \mathrm{C}\right)\end{array}$} & \multirow[b]{2}{*}{$\begin{array}{l}\text { Air velocity, } \\
\mathrm{V}_{\mathrm{a}}\left(\mathrm{ms}^{-1}\right)\end{array}$} & \multicolumn{3}{|c|}{$\begin{array}{l}\text { Infrared power } \\
\text { Drying time (minutes) }\end{array}$} \\
\hline & & $400 \mathrm{~W}$ & $600 \mathrm{~W}$ & $800 \mathrm{~W}$ \\
\hline \multirow[t]{3}{*}{$50^{\circ} \mathrm{C}$} & 0.5 & 687 & 598 & 343 \\
\hline & 1.0 & 652 & 568 & 326 \\
\hline & 1.5 & 639 & 556 & 319 \\
\hline \multirow[t]{3}{*}{$60^{\circ} \mathrm{C}$} & 0.5 & 546 & 478 & 274 \\
\hline & 1.0 & 519 & 454 & 260 \\
\hline & 1.5 & 508 & 445 & 255 \\
\hline \multirow[t]{3}{*}{$70^{\circ} \mathrm{C}$} & 0.5 & 480 & 419 & 240 \\
\hline & 1.0 & 456 & 398 & 228 \\
\hline & 1.5 & 446 & 390 & 223 \\
\hline
\end{tabular}


The drying time reduced to $546 \mathrm{~min}$ when the air temperature was increased from 50 to $60^{\circ} \mathrm{C}$, keeping the infrared power level and air velocity constant at $400 \mathrm{~W}$ and $0.5 \mathrm{~ms}^{-1}$, respectively. A similar drying trend was obtained for the anchovy at other experimental levels of drying air temperature $\left(50\right.$ to $\left.70^{\circ} \mathrm{C}\right)$ and air velocity $\left(0.5\right.$ to $\left.1.5 \mathrm{~ms}^{-1}\right)$.

\subsection{Moisture Content}

The moisture content (Fig. 2) decreased rapidly at the beginning and then decreased slowly with increase in drying time. The drying rate (Fig. 3) decreased continuously with drying time and moisture content. A constant drying rate period was detected approximately at $400 \mathrm{~W}$ of infrared power. The drying times to reduce the moisture content from initial moisture of $78 \pm 1 \% \mathrm{wb}$ to final moisture of $20 \% \mathrm{wb}$ in several conditions are shown in Table 1.

\section{DISCUSSION}

\subsection{Infrared Power}

Heat was supplied to anchovies by electromagnetic radiation from the infrared heater (Cuccurullo et al., 2012). The infrared energy emitted from the heater passes through air and was absorbed by the anchovy (Yunus et al., 2009); the energy was then converted into heat by interaction with molecules in the anchovies (Insorn et al., 2010). With convectional heating, heat was mainly supplied to the surface of the food by convection from circulating hot air.

\subsection{Air Temperature}

The stage of constant surface temperature can be expressed as a first drying stage, which was handled by the external moisture transfer, but the drying velocity observed in the experiments was much slower than the theoretical drying velocity of the first drying stage. The stage of constant surface temperature represents a period of equilibrium between the energy input and the energy consumption for evaporating moisture (Burmester and Eggers, 2010).

\subsection{Air Velocity}

This can decrease the drying time due to the increase in moisture transport and convection (Zlatanovi et al., 2013; Sevik, 2013; Kowalski and Mierzwa, 2013). At the end of drying, the drying velocity decreases, which was probably related to moistural changes of the anchovy.

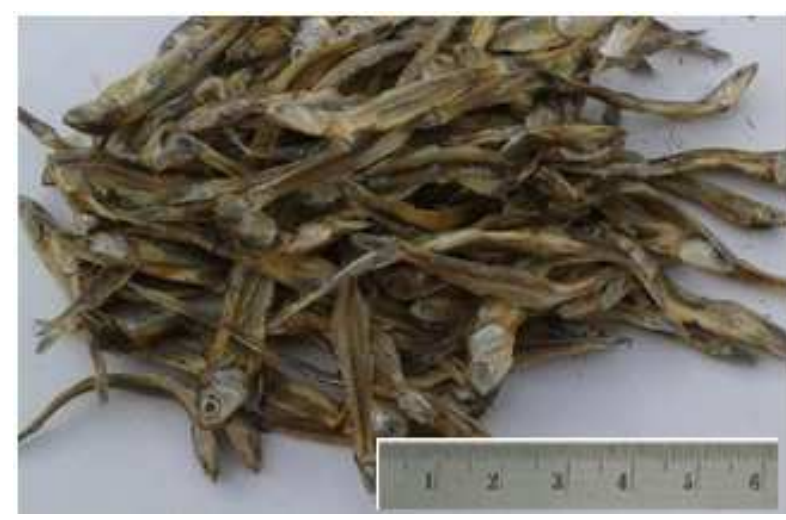

Fig. 4. The dried anchovy after drying at $70^{\circ} \mathrm{C}, 1.5 \mathrm{~ms}^{-1}$ velocity and $800 \mathrm{~W}$ infrared power

\subsection{Quality}

The abundance of free water on the anchovy surface contributed to the effortless moisture liberation; however, it might be much more difficult to expel water after that, when the anchovy surface becomes harder due to shrinkage (Dongbang et al., 2010).

A comparison of the darkness of anchovy after drying between the infrared radiation dryer and sunlit drying was made. There were differences in darkness (Fig. 4). The dried anchovy after using sunlit drying appeared lighter while using the infrared radiation dryer gave darker product. This may be due to the oxidation of carotenoid pigments at the increased temperatures (Ravichandran et al., 2013)

\subsection{Nusselt's Number}

The relation of Nusselt's number to total heat transfer of the anchovy during drying was investigated at air temperatures of $50-70^{\circ} \mathrm{C}$, air velocities of $0.5-1.5$ $\mathrm{ms}^{-1}$ and infrared power of 400-800 W (Fig. 5). In addition, the relation of Nusselt's number to the Reynolds's number of the anchovy drying was investigated at the same drying conditions (Fig. 6).

Equation 13 was calculated by using the least squares method and the calculation result is shown in Equation 19 based on the Reynolds's number range 140 $<\mathrm{Re}_{\mathrm{p}}<1050$ as follows:

$\mathrm{Nu}=\frac{\mathrm{h}_{\mathrm{t}} \mathrm{d}}{\mathrm{k}}=0.685 \operatorname{Re}_{\mathrm{p}}^{0.65} \operatorname{Pr}^{0.35}$

The predicted values from Equation 19 were compared to the experimental values. The simulation results can predict $90 \%$ of the experimental data to within $\pm 10 \%$ deviation (Fig. 7). 


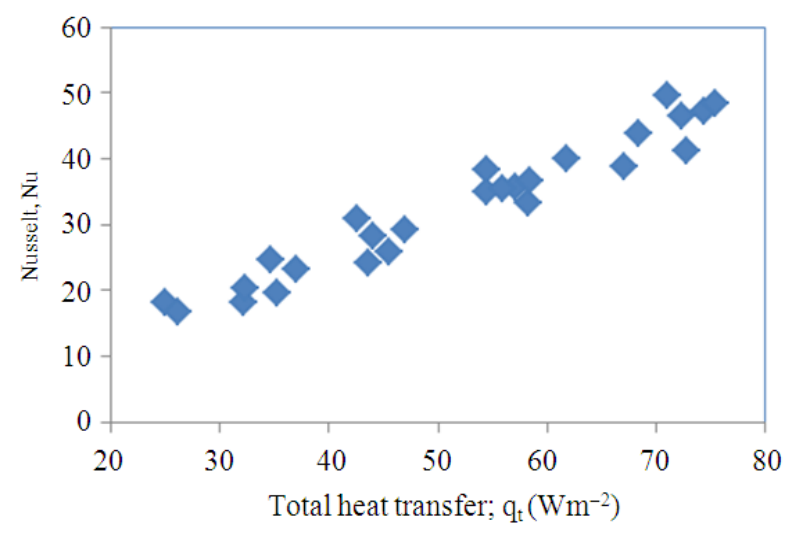

Fig. 5. Relation of Nusselt's number to total heat transfer of the anchovy drying process at $50-70^{\circ} \mathrm{C}, 0.5-1.5 \mathrm{~ms}^{-1}$ velocity and 400-800 $\mathrm{W}$ infrared power

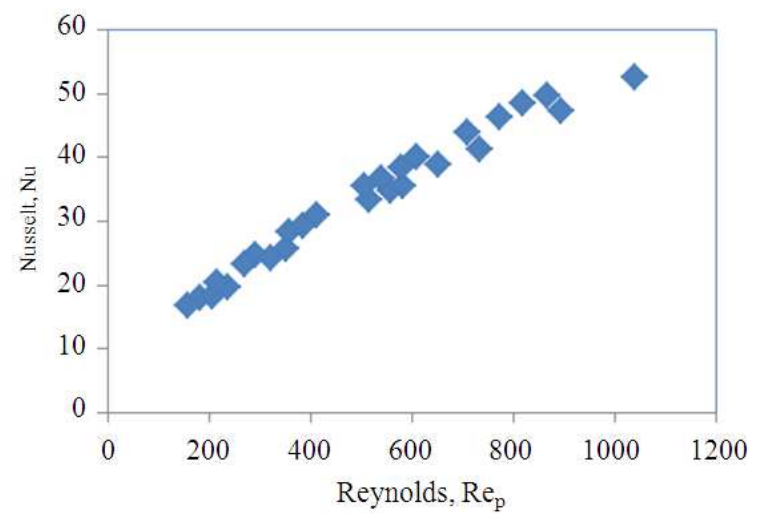

Fig. 6. Relation of Nusselt's number to Reynolds's number of the anchovy drying process at $50-70^{\circ} \mathrm{C}, 0.5-1.5 \mathrm{~ms}^{-1}$ velocity and $400-800 \mathrm{~W}$ infrared power

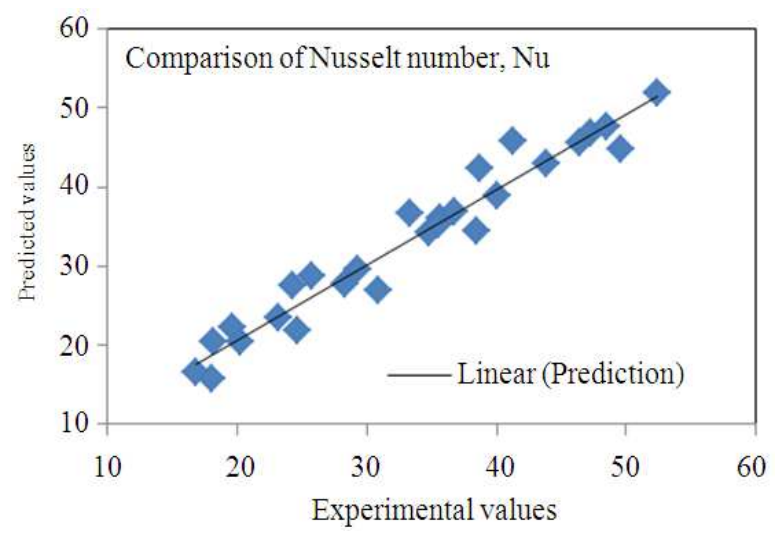

Fig. 7. Comparison of Nusselt's number between the predicted values and experimental values

\section{CONCLUSION}

Anchovy drying using the infrared radiation technique can be concluded as following. The increase of drying temperature $\left(50-70^{\circ} \mathrm{C}\right)$, hot air velocity $(0.5-1.5$ $\left.\mathrm{ms}^{-1}\right)$ and the infrared power $(400-800 \mathrm{~W})$ can increase the performance in evaporating the moisture. In addition, the quality of the dried anchovy can be acceptable. The infrared radiation drying gives a shorter drying time due to the higher heat and mass transfer coefficients compared with the hot air drying. Increase of the infrared power results in a shorter drying time. The modified correlations for predicting the heat transfer coefficient in terms of Nusselt's number for the anchovy drying could fit the experimental data quite well within $\pm 10 \%$ deviation.

\section{ACKNOWLEDGEMENT}

The researchers wish to thank the students for recording the data and the Faculty of Engineering, Burapha University, Thailand for supporting the project "The comparison of performance of Indian anchovy drying using the gravitational and centrifugal fluidized bed technique (16/2555)".

\section{REFERENCES}

Basri, D.F., A. Fudholi and M.H. Ruslan, 2012. Drying characteristics of the borneo Canarium odontophyllum (dabai) fruit. Am. J. Agric. Biol. Sci., 7: 347-356.

Burmester, K. and R. Eggers, 2010. Heat and mass transfer during the coffee drying process. J. Food Eng., 99: 430-436. DOI: 10.1016/j.jfoodeng.2009.12.021

Cuccurullo, G., L. Giordano, D. Albanese, L. Cinquanta and M.D. Matteo, 2012. Infrared thermography assisted control for apples microwave drying. J. Food Eng., 112: 319-325. DOI: 10.1016/j.jfoodeng.2012.05.003

Czerner, M. and M.I. Yeannes, 2013. Modelling the effect of temperature and lipid content on anchovy (Engraulis anchoita) salting kinetics. J. Food Eng., 115: 164-172. DOI: 10.1016/j.jfoodeng.2012.10.004

Dongbang, W., W. Pirompugd and K. Triratanasirichai, 2010. The drying kinetics of chilies using a rotating fluidized bed technique. Am. J. Applied Sci., 7: 1599-1606. DOI: 10.3844/ajassp.2010.1599.1606 
Geetha, P. and M.B.K. Moorthy, 2011. Variable viscosity, chemical reaction and thermal stratification effects on mixed convection heat and mass transfer along a semi-infinite vertical plate. Am. J. Applied Sci., 8: 628-634. DOI: 10.3844/ajassp.2011.628.634

Ghaly, A.E. and K.N. MacDonald, 2012a. An effective passive solar dryer for thin layer drying of poultry manure. Am. J. Eng. Applied Sci., 5: 136-150. DOI: 10.3844/ajeassp.2012.136.150

Ghaly, A.E. and K.N. MacDonald, 2012b. Drying of poultry manure for use as animal feed. Am. J. Agric. Biol. $\quad$ Sci., 7 : 239-254. DOI: 10.3844/ajabssp.2012.239.254

Insorn, W., S. Lee, N. Piantong and A. Janyalertadun, 2010. Cost comparisons in the rice disinfestations between infrared radiations heating application and chemical application. Energy Res. J., 1: 152-157. DOI: 10.3844 /erjsp.2010.152.157

Jaturonglumlert, S. and T. Kiatsiriroat, 2010. Heat and mass transfer in combined convective and farinfrared drying of fruit leather. J. Food Eng., 100: 254-260. DOI: 10.1016/j.jfoodeng.2010.04.007

Kowalski, S.J. and D. Mierzwa, 2013. Numerical analysis of drying kinetics for shrinkable products such as fruits and vegetables. J. Food Eng., 114: 522-529. DOI: 10.1016/j.jfoodeng.2012.08.037

Lovineh, S.G., M. Asghari and B. Rajaei, 2013. Numerical simulation and theoretical study on simultaneous effects of operating parameters in vacuum membrane distillation. Desalination, 314: 59-66. DOI: 10.1016/j.desal.2013.01.005

Niamnuya, C., M. Nachaisinc, N. Poomsa-ad and S. Devahastin, 2012. Kinetic modelling of drying and conversion/degradation of isoflavones during infrared drying of soybean. Food Chem., 133: 946952. DOI: 10.1016/j.foodchem.2012.02.010
Ravichandran, K., N.M.M.T. Saw, A.A.A. Mohdaly, A.M.M. Gabr and A. Kastell et al., 2013. Impact of processing of red beet on betalain content and antioxidant activity. Food Res. Int., 50: 670-675. DOI: 10.1016/j.foodres.2011.07.002

Sevik, S., 2013. Design, experimental investigation and analysis of a solar drying system. Energy Conversion Manage., 68: 227-234. DOI: 10.1016/j.enconman.2013.01.013

Shackelford, C.D. and S.M. Moore, 2013. Fickian diffusion of radionuclides for engineered containment barriers: Diffusion coefficients, porosities and complicating issues. Eng. Geol., 152: 133-147. DOI: 10.1016/j.enggeo.2012.10.014

Yang, D.S. and Q. Xu, 2013. Virtual boundary meshless least square integral method with moving least squares approximation for 2D elastic problem. Eng. Anal. Boundary Elements, 37: 616-623. DOI: 10.1016/j.enganabound.2013.01.006

Yunus, W.M.M., Y.W. Fen and L.M. Yee, 2009. Refractive index and fourier transform infrared spectra of virgin coconut oil and virgin olive oil. Am. J. Applied Sci., 6: 328-331. DOI: 10.3844/ajassp.2009.328.331

Zlatanovi, I., M. Komatina and D. Antonijevi, 2013. Low-temperature convective drying of apple cubes. Applied Thermal Eng., 53: 114-123. DOI: 10.1016/j.applthermaleng.2013.01.012 